\title{
Survey of Environmental Baseline in the Nunukan Agriculture Area, Indonesia
}

\author{
Ramdiana Muis*†, Nani Anggraini**, Fitri Ariani***, Sattar Yunus**** and Zulkifli***** \\ *Department of Urban and Regional Development, Universitas Muhammadiyah, Pare-Pare, 91131, Indonesia \\ **Department of Environmental Engineering, Universitas Bosowa. Makassar, 90231, Indonesia \\ ****Department of Chemical Engineering, Universitas Bosowa. Makassar, 90231, Indonesia \\ ****Department of Mechanical Engineering, Universitas Muslim Indonesia, Makassar, 90231, Indonesia \\ *****Department of Agriculture, Universitas Muslim Maros, Maros, 90511, Indonesia \\ $†$ Corresponding author: Ramdiana Muis; ramdiana.uts@gmail.com
}

Nat. Env. \& Poll. Tech.

Website: www.neptjournal.com

Received: 29-03-2020

Revised: $28-04-2020$

Accepted: 21-06-2020

Key Words:

Environmental baseline

Water quality

Air quality

Soil quality

Agriculture area

Nunukan Regency

\section{ABSTRACT}

South Nunukan District has a complex ecosystem which has the river, terrestrial, coastal and oceanic ecosystems, and has been demarcated by the Government of The Nunukan Regency for agricultural purposes. This research was conducted to determine the preliminary environmental baseline of agricultural activities that have been and will take place in this region. Methods of measuring environmental quality were carried out by (1) measuring water quality by taking water samples at four locations and tested in a laboratory; and also measuring aquatic biota by taking samples in rivers and testing at a laboratory, (2) measuring air quality at three sample locations using an air quality meter, and noise using a sound level meter, (3) measuring soil quality by taking five samples at the study site and conducting soil quality testing in the laboratory. The result of this study concluded that this area is suitable to be used as an agriculture and plantation area by adding various engineering technologies and fertilizing. This is supported by the results of water, air, noise and soil quality tests from several samples showing the average within and bellow the permissible limit (WPL and BPL). For a small number of parameters that do not meet quality standards (APL), environmental engineering efforts need to be done.

\section{INTRODUCTION}

The progressive development of cities in the world including the Industrial Acceleration in the last two decades has brought many impacts on the environment, which are caused by pollution in water, soil and air that in turn can disturb human health (World Health Organization 2002, Sattar et al. 2012, Rashid et al. 2014).

Indonesia is an archipelagic country and Nunukan island is one of the islands located in the Kalimantan region. Based on the Spatial Plan of the Nunukan Regency 2013-2033, the South Nunukan District is intended for agriculture and plantation areas. To support these objectives, environmental conditions that are appropriate for their purpose are needed. South Nunukan District is geographically affected by river ecosystems (Tanjung Harapan River), terrestrial, coastal and oceanic ecosystems so that this region has complex conditions.

As an area designated for food storage, water is a vital part because it is a basic need for irrigation and other agricultural needs (Kumari et al. 2009). The rise of population, modern agriculture, and industrialization can put gigantic pressure on freshwater bodies, causing a threat to mankind's healthy existence (Karne et al. 2009). To reduce the environmental damage caused by development, preliminary studies are needed to see the baseline environment, this is aimed at realizing sustainable development (Sari et al. 2014).

This study has been conducted to evaluate environmental parameters in water, air and soil. Furthermore, water quality has been measured in several areas such as a river, reservoir, surface water and groundwater around South Nunukan District. The assessment of water quality can support the function of the land. By using water variable, this study measures the physicochemical and biological characteristics of the water body and groundwater as study areas and compare them to The Indonesian Government Regulation Number: 82 of 2001, concerning Water Quality Management, Control and Diversity Index of Shannon-Wiener.

Also, measurements of air quality and noise were carried out around South Nunukan District where most of the cities in Indonesia have been reported for particulate air pollution and give an impact on the environment (Sattar et al. 2014, Saini et al. 2018, Sattar et al. 2019). Finally, soil quality was also analysed to determine soil fertility in the study area. 


\section{MATERIALS AND METHODS}

\section{Study Area Description}

The population of South Nunukan District in 2018 was 26,827 occupying an area of $174.4 \mathrm{~km}^{2}$. Population growth that occurred as a result of the development was almost evenly distributed in each district so that it attracted newcomers to live and settle in South Nunukan subdistrict. The opening of employment in the plantation sector, especially oil palm and the wood processing industry and the service sector was another reason why more people feel attracted to move and live here (BPS-Statistics of Nunukam Regency 2016).

The South Nunukan district is located around the catchment of the Tanjung Harapan River in Nunukan Island and situated on the edge of the southern coast (117 $40^{\prime} 34.39^{\prime}$ " E, 3 $\left.{ }^{\circ} 58^{\prime \prime} 25.36 " N\right)$. This area was planned as an integrated agricultural production zone. This land is called transitional swampland or tidal swamp where the strength of tidal currents from the sea is slightly greater or equal to the strength of currents from the headwaters of the river. Fig. 1 shows the location of the island.

\section{Sampling Methods}

The sampling sites are shown in Fig. 1. The samples were collected at four areas including river, groundwater, surface water and reservoir water in the South Nunukan District in plastic bottles before rinsing them with the sample water. The water samples were then brought to the laboratory for physicochemical quality and biological parameters testing. The methods follow The Indonesian Government Regulation Number: 82 of 2001, concerning Water Quality Management and Control.

Biological measurement was done using the indicator of aquatic biota (Holt \& Miller 2010). Plankton was sampled

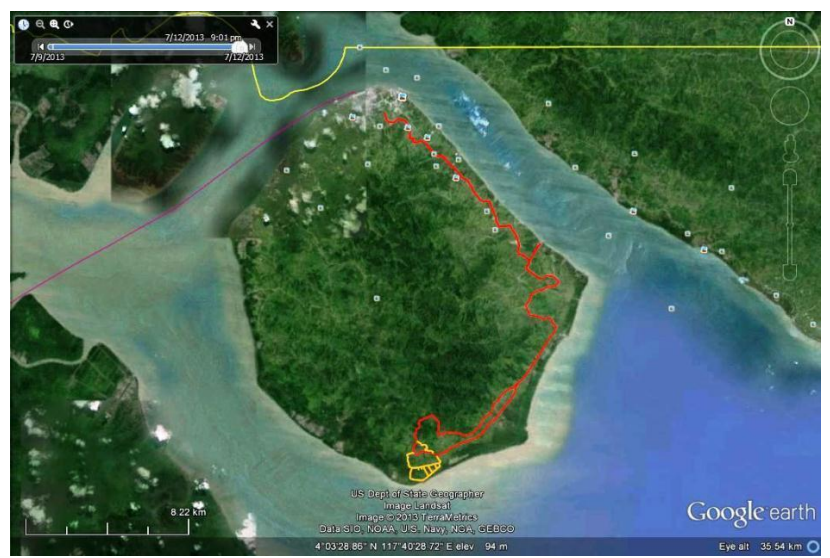

(Source: Google Earth, 2020)

Fig. 1: The location map. using a plankton net by filtering 100 litres of water. Then, it was stored in $10 \mathrm{~mL}$ plankton bottles and preserved with $4 \%$ formalin solution to be observed in the laboratory. The plankton was separated into phytoplankton and zooplankton groups, to determine the diversity of species and their abundance. Plankton's determination was made by using the key of plankton determination made by Shirota (1966).

For air quality measurements, samples were taken from 3 locations and the measurement was made at the site using an ambient gas sampler (Impinger Model: MD-51MP), while measurement of noise levels at locations using a sound level meter.

To determine the level of soil fertility in the study area, identification and analysis of the physical (sand, dust and clay) and chemical properties of the soil were carried out through soil analysis, i.e. $\mathrm{pH}, \mathrm{C}, \mathrm{N}, \mathrm{C} / \mathrm{N}, \mathrm{P}_{2} \mathrm{O}_{5}, \mathrm{Ca}, \mathrm{Mg}$, $\mathrm{K}, \mathrm{Na}, \mathrm{KTK}$ and BK. The soil samples were taken from 5 locations and brought to the laboratory for analysis with reference to the guidelines of soil analysis (BPN-Institute of Soil Research 2003).

\section{RESULTS AND DISCUSSION}

\section{Water Quality}

The results of the study for all parameters are given in Table 1. Based on various physicochemical parameters, each water sample was classified into within permissible limits (WPL), below permissible limits (BPL) and above permissible limits (APL).

The Total Dissolved Solids (TDS) is defined as the total amount of the solid material dissolved in water containing salts, dangerous metals and other materials in water. The results of the analysis of TDS in Sample 4 (S4) are higher than those of Sample 1, Sample 2 and Sample 3. The order of TDS concentration found at the sampling site was S4 > $\mathrm{S} 1>\mathrm{S} 3>\mathrm{S} 2$, even the concentrations in S4 and S1 exceed the permissible limit $(1000 \mathrm{mg} / \mathrm{L})$. The results of these measurements indicate that the river water in the planned location of the activity has been polluted. The sulphates showed the highest concentration at $\mathrm{S} 4(489,881 \mathrm{mg} / \mathrm{L})$ which exceeds the permissible limit (400 mg/L), while S1, S2 and S3 have still below the permissible limit. The dissolved oxygen (DO) exceeds the permissible limit ( $>6 \mathrm{mg} / \mathrm{L}$ ) at all the 4 sample locations, while the total phosphorus as $\mathrm{P}$ was only present at $\mathrm{S} 1$ which exceeds the permissible limit $(0.2 \mathrm{mg} / \mathrm{L})$ with a concentration value of $0.872 \mathrm{mg} / \mathrm{L}$. The concentration of $\mathrm{P}$ at $\mathrm{S} 1, \mathrm{~S} 2$ and $\mathrm{S} 3$ were not below the detection limit.

The measurement of water quality in Table 1 shows that the Dissolved Oxygen (DO), $\mathrm{Cl}$, and sulphate parameters are high, but these values are considered to still meet the class 
Table 1: The physicochemical, dissolved metal and microbiological parameters of 4 water samples in the South Nunukan District.

\begin{tabular}{|c|c|c|c|c|c|}
\hline Physic Parameters & $\mathrm{S} 1$ & $\mathrm{~S} 2$ & S3 & S4 & PL \\
\hline Temperature & 28 & 28 & 28 & 28 & \\
\hline TDS & $1350(-)$ & 144 & 296 & $5628(-)$ & 1000 \\
\hline TSS & 23.6 & 10.8 & 13.2 & 4 & 50 \\
\hline Dissolved Metal Parameters & S1 & S2 & S3 & S4 & \\
\hline As & - & - & - & - & 0.05 \\
\hline Co & - & - & - & - & 0.2 \\
\hline $\mathrm{Ba}$ & - & - & - & - & 1 \\
\hline $\mathrm{Br}$ & - & - & - & - & 1 \\
\hline $\mathrm{Se}$ & - & - & - & - & 0.01 \\
\hline $\mathrm{Cd}$ & $<0.0003$ & $<0.0003$ & $<0.0003$ & $<0.0003$ & 0.01 \\
\hline $\mathrm{Cr}^{6+}$ & 0 & 0 & 0 & 0 & 0.05 \\
\hline $\mathrm{Cu}$ & $<0.0001$ & $<0,0001$ & 0,0066 & 0.0066 & 0.02 \\
\hline $\mathrm{Fe}$ & $0.463(-)$ & 0.015 & 0.118 & 0.041 & 0.3 \\
\hline $\mathrm{Pb}$ & $<0.0074$ & $<0.0074$ & $<0.0074$ & $<0.0074$ & 0.03 \\
\hline $\mathrm{Mn}$ & $<0.0001$ & $<0.0001$ & $<0.0001$ & $<0.0001$ & 0.1 \\
\hline hg & - & - & - & - & 0.001 \\
\hline $\mathrm{Zn}$ & $<0.0001$ & $<0.0001$ & $<0.0001$ & $<0.0001$ & 0.05 \\
\hline $\mathrm{Cl}$ & $547.836(-)$ & $15.762(-)$ & $15.762(-)$ & $102.24(-)$ & 600 \\
\hline $\mathrm{CN}$ & - & - & - & - & 0.02 \\
\hline Fluoride & - & - & - & - & 0.5 \\
\hline $\mathrm{NO}_{2}$ as $\mathrm{N}$ & 0 & 0 & 0 & 0 & 0.06 \\
\hline Sulphate & $51.079(-)$ & $19.693(-)$ & $74.644(-)$ & $489.881(-)$ & 400 \\
\hline $\mathrm{Cl}_{2}$ & 0 & 0 & 0 & 0 & 0.03 \\
\hline $\mathrm{H}_{2} \mathrm{~S}$ & 0 & 0 & 0 & 0 & 0.002 \\
\hline Microbiological Parameters & S1 & S2 & S3 & S4 & \\
\hline Coliform & 93 & 23 & 32 & 14 & 1000 \\
\hline Chemical Parameters & S1 & S2 & S3 & S4 & \\
\hline $\mathrm{pH}$ & 7.29 & 6.94 & 7.02 & 7.09 & $6.0-9.0$ \\
\hline BOD & 1.044 & 0.959 & 0,98 & 0.928 & $<2$ \\
\hline COD & 5.493 & 5.049 & 5.16 & 4.882 & $<10$ \\
\hline DO & $6.972(-)$ & $7.049(-)$ & $6.962(-)$ & $7.418(-)$ & $>6$ \\
\hline Total Phosphate as P & $0.872(-)$ & 0 & 0 & 0 & 0.2 \\
\hline $\mathrm{NH}_{3}-\mathrm{N}$ & 0.097 & 0 & 0.436 & 0.989 & 10 \\
\hline
\end{tabular}

*Where: (-)= Above permissible limits, - = Not Analysed; $0=$ Not detected

*Where: S1-River Water, S2-Groundwater, S3-Surface Water, S4-Reservoir Water, PL-Permissible Limit

I water criteria based on Government Regulation Number 82 Year 2001, concerning Water Quality Management and Control Water Pollution.

The phosphate $(\mathrm{P})$ is above the permissible limit at the S1 (river water) test location, this shows the occurrence of river pollution by agricultural fertilizers entering the river water through drainage and rainwater flow. This causes high growth of algae in river water (eutrophic condition) which will cause the reduction of dissolved oxygen endangering the river water ecosystem. Table 2 gives the range of plankton diversity index which is 1.32 , this value shows that the quality of river waters is in the moderate polluted category. The uniformity and dominance index show stable conditions and there is no type of plankton domination.

According to Wilhm (1975), based on the zoobenthos diversity index, water quality can be categorized as heavily 
Table 2: The phytoplankton of Tanjung Harapan river samples in the South Nunukan District.

\begin{tabular}{|c|c|c|c|}
\hline Phytoplankton & $\begin{array}{l}\text { Result } \\
\text { (ind } / \mathrm{m}^{3} \text { ) }\end{array}$ & Benthos & $\begin{array}{l}\text { Result } \\
\left(\text { ind } / \mathrm{m}^{3}\right)\end{array}$ \\
\hline Asterionella sp. & 166 & Corbicula & 95 \\
\hline Skeletonema sp. & 166 & Melanoides sp. & 31 \\
\hline Chaetoceros sp. & 333 & Pilsbryconcha sp. & 31 \\
\hline \multicolumn{4}{|l|}{ Zooplankton } \\
\hline Moina sp. & 166 & & \\
\hline Plankton & & Makrozobenthos & \\
\hline Total Abundance & $\begin{array}{l}831 \\
\left(\mathrm{ind} / \mathrm{m}^{3}\right)\end{array}$ & Total Abundance & $\begin{array}{l}157 \\
\left(\text { ind } / \mathrm{m}^{3}\right)\end{array}$ \\
\hline Number of types & 4 types & Number of types & 3 types \\
\hline Diversity Index & 1.32 & Diversity Index & 0.94 \\
\hline Uniform Index & 0.96 & Uniform Index & 0.85 \\
\hline Dominance Index & 0.28 & Dominance Index & 0.56 \\
\hline
\end{tabular}

*Where: (-) Above permissible limits

polluted $\left(0<\mathrm{H}^{\prime}<1\right)$, moderate polluted $\left(1<\mathrm{H}^{\prime}<2\right)$, lightly polluted $\left(2<\mathrm{H}^{\prime}<3\right)$ and is very lightly polluted $(3<\mathrm{H}<$ 4.5). The range of $H^{\prime}$ values is part of an assessment of water quality with the physical chemistry of water. Lee et al. (1978) stated that the diversity index value $\left(\mathrm{H}^{\prime}\right)$ in heavily polluted waters, smaller than one $\left(\mathrm{H}^{\prime}<1\right)$, moderately polluted $(1.0-$ 1.5), lightly polluted (1.6-2.0), and not contaminated by a large $\mathrm{H}$ of two $(\mathrm{H}>2.0)$. The category of water quality and pollution level based on Shannon-Weiner's macrozoobenthos diversity index are divided into four groups, as given in Table 3.

The macrozoobenthos community of the three river water stations has a density of a range of 157 individuals $/ \mathrm{m}^{3}, 3$ types of macrozoobenthos which belong to 2 groups, including Bilvalvia, 2 types namely Corbicula $\mathrm{sp}$. and Pilsbryoconcha sp., Gastropod Class 1 types namely Melanoides sp.

The results of the diversity index analysis show that the waters of the river have been heavily polluted, the range of diversity index is $<1$, as well as the index of uniformity, the range of 0.85 indicates the individual distribution of each species in heavy and unstable conditions, while the level of dominance index tends to be high at 0.56 shows that some types dominate abundance or that each individual cannot

Table 3: Pollution rate classification (Lee 1978).

\begin{tabular}{|lll|}
\hline Shannon Index & Water Quality & Pollutant Category \\
\hline$<1$ & Slight & Heavy Pollution \\
$>1-2$ & Light & Moderate Pollution \\
$>2-3$ & Moderate & Light Pollution \\
$>3-4.5$ & Good & Moderate Pollution/Not Polluted \\
$>4.5$ & Heavy & Not Polluted \\
\hline
\end{tabular}

utilize resources optimally. It seems that there are more abundant species than other types.

\section{Air Quality}

Based on the results of the measurement of air quality using the Indonesian Standard Number 41 of 1999, concerning the Quality Standards of the National Ambient, all parameters are below permissible limits (BPL) which indicates that air pollution does not occur, as given in Table 4.

\section{Noise Quality}

Based on the results of noise measurement using the Indonesia Minister of Environment Standard Number 48/ MENLH/II/1996 concerning Noise Level Standards, no air pollution occurs (BPL) because there is no value above 70 dBA (Table 5).

\section{Soil Quality}

Laboratory analysis results in Table 6 show that in general soil conditions at the study site have moderate fertility with clay texture about $33-47 \%$ clay composition.

Soil fertility was relatively low, especially for the macro nitrogen element, but has a moderate phosphating content. Levels of organic soil C are very low at $1.64-2.69 \%$ of the ideal $5 \%$, so fertilization with organic fertilizer is highly recommended before planting. The content of macroelements $\mathrm{N} 0.16-0.21 \%$ or very low to low, this requires the addition of urea fertilizer large enough to meet the needs of plant nitrogen.

Fig. 2 presents information about the general soil conditions in South Nunukan Subdistrict, Nunukan Regency which has a moderate fertility rate with a clay texture having 33$47 \%$ clay composition, $15-31 \%$ dust and the $4 \%$ sand. Soil fertility is relatively low, especially for the macro nitrogen element but it has a good phosphate content. The type of

Table 4: Air Quality in The South Nunukan District.

\begin{tabular}{|llll|}
\hline Parameter & $\mathrm{S}-1$ & $\mathrm{~S}-2$ & $\mathrm{~S}-3$ \\
\hline Sulphur Dioxide $\left(\mathrm{SO}_{2}\right)$ & 20.879 & 26.098 & 24.326 \\
Carbon Monoxide $(\mathrm{CO})$ & 39.502 & 25.393 & 19.220 \\
Nitrogen Dioxide $\left(\mathrm{NO}_{2}\right)$ & 23.786 & 40.588 & 35.365 \\
\hline
\end{tabular}

Where: S1-River Water, S2-Groundwater, S3-Surface Water, S4-Reservoir Water

Table 5: Noise measurement.

\begin{tabular}{|lllll|}
\hline Parameter & S-1 & S-2 & S-3 & PL \\
\hline dBA & 52.6 & 47.3 & 45.1 & 70 \\
\hline
\end{tabular}

Where: S1-River Water, S2-Groundwater, S3-Surface Water, S4-Reservoir Water, PL: Permissible Limit 
Table 6: The results of soil analysis samples.

\begin{tabular}{|llllll|}
\hline Soil Parameter & S1 & S2 & S3 & S4 & S5 \\
\hline $\mathrm{pH}$ & 4.2 & 3.8 & 5.5 & 4.9 & 4.5 \\
$\mathrm{C}$ & 2.21 & 1.89 & 2.14 & 2.69 & 1.64 \\
$\mathrm{~N}$ & 0.17 & 0.16 & 0.18 & 0.21 & 0.16 \\
$\mathrm{C} / \mathrm{N}$ & 13 & 12 & 12 & 13 & 10 \\
$\mathrm{P} 2 \mathrm{O} 5$ & 9.23 & 8.24 & 7.66 & 10.56 & 9.33 \\
$\mathrm{Ca}$ & 4.26 & 3.52 & 3.22 & 2.98 & 4.13 \\
$\mathrm{Mg}$ & 2.16 & 1.63 & 1.89 & 1.99 & 2.07 \\
$\mathrm{~K}$ & 0.25 & 0.19 & 0.33 & 0.21 & 0.17 \\
$\mathrm{Na}$ & 0.39 & 0.24 & 0.22 & 0.26 & 0.27 \\
$\mathrm{KTK}$ & 23.07 & 24.32 & 24.36 & 21.85 & 21.66 \\
$\mathrm{~KB}$ & 31 & 23 & 23 & 25 & 31 \\
Texture & & & & & 49 \\
a. Sand & 41 & 35 & 29 & 34 & 15 \\
b. Dust & 15 & 32 & 24 & 31 & 36 \\
c. Clay & 44 & 33 & 47 & 35 & Sand Clay \\
Texture Class & Clay & Clay Stick & Clay & Clay Stick & \\
\hline
\end{tabular}
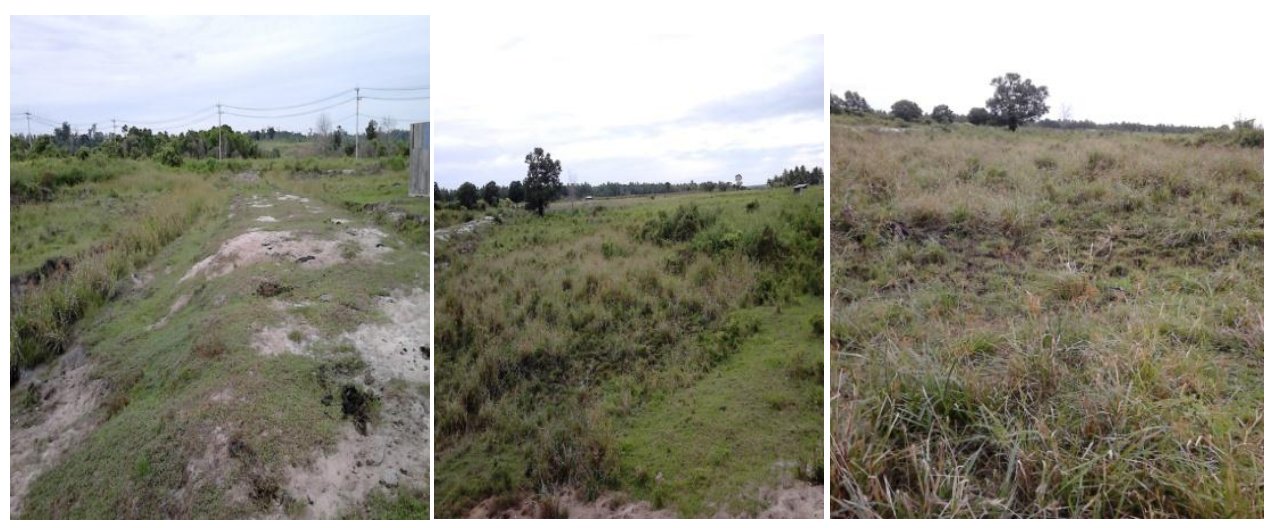

Source: Survey, 2015

Fig. 2: Land condition.

soil has less organic matter so that it can stabilize the soil structure and be resistant to erosion. The content of organic matter determines the sensitivity of the soil to erosion as the organic matter affects the structure of the soil. Soils that contain enough organic matter generally cause the soil structure to become stable so that it is resistant to soil erosion (Sarief 2001). Organic soil C levels are very low, i.e. 1.64-2.69\% of the ideal $5 \%$, so fertilization with organic fertilizer is highly recommended before planting rice to enable the soil in binding water be maximized. The content of macroelements $\mathrm{N}$ $(0.16-0.21 \%)$ or very low to low level and this requires the addition of urea fertilizer large enough to meet the needs of plant nitrogen (Hanafiah 2010).

\section{CONCLUSION}

Based on the environmental baseline data of the South Nunukan District, it can be concluded that this area is suitable to be used as an agriculture and plantation area in accordance with The Nunukan Regional Spatial Plan (2013-2033) by adding various engineering technologies and fertilizing.

This is supported by the results of water, air, noise and soil quality tests from several samples showing the average below permissible limit (BPL). It was found that for some parameters, which did not meet the quality standards, some environmental engineering actions should be taken. 


\section{REFERENCES}

BPN-Institute of Soil Research 2003. Guidelines of Soil Analysis.

BPS-Statistics of Nunukam Regency 2016. Nunukan Regency of Figure 2016.

Karne, A.V. and Kulkarni, P.D. 2009. Studies on physico-chemical characteristics of freshwater bodies in Khatav Tahsil, Maharashtra. Nature Environment and Pollution Technology, 8(2): 247-251.

Hanafiah, K.A. 2010. Fundamentals of Soil Sciences. Rajawali Press, Jakarta.

Holt, E.A. and Miller, S.W. 2010. Bioindicators: Using organisms to measure environmental impacts. Nature Education Knowledge, 3(10): 8.

Kumari, S.B., Priyatharshini, K., Julie, M.P. and Manimegalai, M. 2009. Study of well waters in the area around paper mill industry, Udumalpet, Tamilnadu. Nature Environment and Pollution Technology, 8(4): 845-847.

Lee, C.D., Wang, S.B. and Kuo, C.L. 1978. Benthic macroinvertebrate and fish as biological indicators of water quality, with reference of community diversity index. International Conference on Water Pollution Control in Development Countries, Bangkok.

Rashid, M., Sattar, Y., Ramli, M., Sabariah. and Puji, L. 2014. PM 10 black carbon and ionic species concentration of urban atmospheric in Makassar of South Sulawesi Province, Indonesia. Atmospheric Pollution Research, 5: 610-615. doi: 10.5094/APR.2014.070.

Saini, M., Rusdi, N., Sattar, Y. and Ibrahim. 2018. The influence of throat length and vacuum pressure on air pollutant filtration using ejectors. AIP Conference Proceedings, doi.org/10.1063/1.5042939.

Sari, T.G.F., Makmur, M. and Rozikin, M. 2014. Effectiveness of UKL-UPL Implementation in reducing environmental damage (study at the Malang Regency Environmental Agency and Communities around PT Tri Surya Plastik District Lawang). Jurnal Administrasi Publik (JAP), 2(1): 161-168.

Sarief, E.S. 2001. Fertility and Fertilization of Agricultural Land. Pustaka Buana, Bandung.

Sattar, Y., Rashid, M., Ramli, M. and Sabariah, B. 2014. Black carbon and elemental concentration of ambient particulate matter in Makassar Indonesia. IOP Conf. Series: Earth and Environmental Science, 18. 012099. doi: 10.1088/1755-1315/18/1/012099.

Sattar, Yunus. Mohd. Rashid., Ramli Mat., Sabariah Baharun and Hasfalina C. Man 2019. Characteristics of the $\mathrm{PM}_{10}$ in the urban environment of Makassar, Indonesia. Journal of Urban and Environmental Engineering, 13(1): 198-201. doi: 10.4090/juee.2009.v13n1.198207.

Sattar., M. Rashid., R. Mat. and L. Puji 2012. A preliminary survey of air quality in Makassar City South Sulawesi Indonesia. Jurnal Teknologi (Sciences \& Engineering), 57: 123-136.

Shirota, A. 1996. The plankton of South Vietnam. Overseas Technology Coop. Agency Japan, pp. 416.

WHO 2002. The World Health Report 2002: Reducing Risks, Promoting Health Life, World Health Organization, Geneva.

Wilhm, J. F. 1975. Biological indicator of pollution. In: Whitton, B.A. (editor). River Ecology. Blackwell Scientific Publications. Oxford, London, pp. 370-402. 